\title{
A type-specific nested PCR assay established and applied for investigation of HBV genotype and subgenotype in Chinese patients with chronic HBV infection
}

Jing-Jing Nie, Kui-Xia Sun, Jie Li', Jie Wang, Hui Jin, Ling Wang, Feng-Min Lu, Tong Li, Ling Yan, Jing-Xian Yang, Mi-Shu Sun and Hui Zhuang*

\begin{abstract}
Background: Many studies have suggested that hepatitis B virus (HBV) genotypes show not only geographical distribution and race specificity, but also are associated with disease progression and response to interferon treatment. The objective of this study was to develop a nested polymerase chain reaction (nPCR) assay for genotypes A-D and subgenotypes B1, B2, C1 and C2 of hepatitis B virus (HBV) and to investigate the distribution characteristics of HBV genotypes/subgenotype in China.

Methods: After redesigning the primers and optimizing the reaction conditions using common Taq polymerase, the sensitivity, specificity and reproducibility of the method were evaluated using plasmids and serum samples. In total, 642 serum samples from patients with chronic HBV infection were applied to investigate the distribution of HBV genotype and subgenotype in China.

Results: The genotype and subgenotype could be identified when the HBV DNA load of a sample was $\geq 10^{2.3} \mathrm{IU} / \mathrm{mL}$. For the 639 successfully genotyped samples, the sequencing results of 130 randomly selected samples $(20.3 \%, 130 / 639)$ were consistent with those of the nPCR method. The present study showed that HBV genotype B (11.2\%, 72/642), C (68.2\%, 438/642) and D (7.2\%, 46/642) were circulating in China, while genotype C was the dominant strain except for western region where genotype $D$ was the prevalent strain. The main subgenotypes of genotypes B and C were B2 $(87.5 \%, 63 / 72)$ and C2 $(92.9 \%, 407 / 438)$, respectively.

Conclusions: The low-cost nPCR method would be a useful tool for clinical and epidemiological investigation in the regions where genotypes A-D are predominant.
\end{abstract}

Keywords: Genotype, Hepatitis B virus, Nested PCR, Subgenotype, Type-specific nested PCR

\section{Background}

An increasing number of studies have suggested that hepatitis B virus (HBV) genotypes show not only geographical distribution and race specificity, but also are associated with disease progression and response to interferon treatment $[1,2]$.

According to sequence divergence of greater than $8 \%$ over the entire genome, or greater than $4 \%$ for the $\mathrm{S}$ gene, $\mathrm{HBV}$ has been classified into eight different genotypes A-H

\footnotetext{
*Correspondence: Jielipku@gmail.com; zhuangbmu@126.com

Department of Microbiology, School of Basic Medical Sciences, Peking University Health Science Center, Beijing 100191, China
}

[3-6]. Different subgenotypes for each genotype have also been identified and defined by sequence divergence of between $4 \%$ and $8 \%$ of the full genome [7].

Hepatitis B is endemic in China, with a hepatitis B surface antigen (HBsAg) carrier rate of 7.18\% [8]. HBV molecular epidemiological studies showed that genotypes B and $C$ were predominant in China. Genotype A (few and scattered), D (predominant in Uyghur patients of Xinjiang) and C/D recombinant (mainly found in Tibet) were also detected in China $[9,10]$. The predominant subgenotype of $\mathrm{B}$ was $\mathrm{B} 2$, and that of $\mathrm{C}$ was $\mathrm{C} 2$, while $\mathrm{B} 1$ and $\mathrm{C} 1$ were also present in China [11]. 
There are several methods for HBV genotyping. Sequence analysis of the entire genome [3] or of the $\mathrm{S}$ gene [4] is considered as the gold standard for genotyping. Other methods include type-specific PCR [12-15], restriction fragment length polymorphism assay (RFLP) [16-18], line probe assay [19], and specific monoclonal antibody assay $[20,21]$, etc. Among these methods, the type-specific PCR method has been used widely for clinical and epidemiological surveys due to its rapid detection, low cost, high specificity and sensitivity, and superior results for the diagnosis of mixed infections [22].

Dr. Naito and his colleagues developed a type-specific nPCR method for genotyping of HBV in 2001 [15], and it was considered as a classical method. Following Naito's method, one round type-specific PCR (multiplex PCR) methods was developed by some scholars [12-14]. Our lab adopted Naito's method for genotyping since 2002. However, in long-term use of the method in our lab, it was found that the specificity of the method was reduced when common Taq polymerase was employed instead of AmpliTaqGold DNA polymerase (unpublished data). Moreover, Naito's method could not identify subgenotypes directly. Among one round type-specific PCR, Chen's method [12] was reported to be superior in specificity and sensitivity, and could distinguish subgenotypes in another reaction. However, our study showed that the sensitivity of the method for genotypes $B$ and $C$ was $>10^{4} \mathrm{IU} / \mathrm{mL}$ (the procedures exactly followed those as reported). Other studies also showed similar results about the sensitivity of Chen's method [23,24].

Considering the importance of genotyping and subgenotyping of HBV in clinical and epidemiology surveys, a more specific, sensitive and low-cost method is required.

This study established a type-specific nPCR assay for genotypes A-D and main subgenotypes of HBV B and C, based on modification of the PCR method developed by Naito et al., (2001) [15], and it was applied to investigate the distribution of HBV genotypes and subgenotypes in China. Using this method, 642 samples from patients with chronic HBV infection from nine provinces in China were assayed.

\section{Methods}

\section{Samples}

Plasmids containing genomic DNA of HBV genotype A [25], genotype D [26], subgenotype B1 [27] and subgenotype C2 [25] were employed in this study. Serum samples of HBV subgenotype $\mathrm{B} 2$ and $\mathrm{C} 1$, which were confirmed by sequencing, were employed as standard sera [GenBank: JQ416307, JQ416308]. All of the samples were stored at $-80^{\circ} \mathrm{C}$ before testing.

One hundred and twenty seven serum samples were selected randomly from the serum bank and were used for evaluating the sensitivity of the nPCR method. All of the samples with an HBV DNA load of $\geq 10^{2.3} \mathrm{IU} / \mathrm{mL}$ could be genotyped. A further 543 samples with an HBV DNA load of $\geq 10^{2.3} \mathrm{IU} / \mathrm{mL}$ were then selected from the serum bank. Therefore, a total of 642 clinical serum samples from patients with chronic HBV infection were enrolled in this study.

These serum samples enrolled in this study were collected from the east (Shandong and Jiangsu), the west (Xinjiang), the south (Guangdong and Guangxi), the north (Beijing and Jilin) and the central part (Hebei and Henan) of China. All the samples were obtained from patients with chronic HBV infection. Among the 642 samples, 36 were from Jilin (The First Affiliated Hospital of Jilin University), 163 were from Beijing (Beijing Ditan Hospital), 61 were from Guangdong (Peking University Shenzhen Hospital), 49 were from Guangxi (Guangxi Provincial Center for Disease Control and Prevention), 24 were from Shandong (Shandong Jining Infectious Disease Hospital), 124 were from Jiangsu (Jiangsu Provincial Center for Disease Control and Prevention), 118 were from Xinjiang (The First Affiliated Hospital of Xinjiang Medical University), 32 were from Henan (Zhengzhou Municipal Center for Disease Control and Prevention) and 35 were from Hebei (Handan Municipal Center for Disease Control and Prevention).

Informed consent was obtained from each patient at the time that serum samples were collected for the purpose of HBV testing. The serum samples were transported on dry ice and stored at $-80{ }^{\circ} \mathrm{C}$ in our lab until analyzed.

The study was approved by the Ethics Committee of Peking University Health Science Center in accordance with the Helsinki Declaration.

\section{Primer design}

For primer design, 150 entire nucleotide sequences of HBV genotypes A-H were retrieved from GenBank, and analyzed by DNAStar software. Primers were then designed in the conserved regions of the HBV genome by Primer Premier 5.0 software. Primer sequences within the same genotype or subgenotype differed by $\leq 2$ nucleotides (a strict match at the 3 ' end was ensured), while primer sequences differed by $\geq 3$ nucleotides (usually $\geq 2$ nucleotides at the 3 ' end) among the different genotypes or subgenotypes. Some primers were modified by nucleotide substitutions in the middle or at the 5 ' end of primers to avoid intra- or inter-primer dimer formation.

The first round PCR primers (outer primer pairs) were designed in the regions of partial $\mathrm{X}$-PreC/C genes (primers BF and HBAS-4 V) and partial P-PreS/S genes (primers PF and S4R) for the amplification of all A-D genotypes. In the second round amplification, three 
reactions were performed flexibly using 3 mixes containing multiple primers. Mix A contained sense primers HB (type B specific), DF (type D specific), C1F (subgenotype $\mathrm{C} 1$ specific), $\mathrm{C} 2 \mathrm{~F}$ (subgenotype $\mathrm{C} 2$ specific) and antisense common primers BJA-RV and PR. These primers were used to identify genotypes $\mathrm{B}, \mathrm{D}$ and subgenotypes C1, C2. Mix B contained sense primers AF1, AF2 and antisense primer BA1R (AF1 and AF2 were degenerate primers, all three primers were type A specific). These primers were used to identify genotype A. Mix C contained sense primer HB (type B specific) and antisense primers BA (subgenotype B2 specific), BJ (subgenotype $B 1$ specific). These primers were used to identify subgenotypes B1 and B2. Genotypes A-D and subgenotypes B1, B2, C1 and C2 could be differentiated based on the length of the PCR products. HBAS-4 V and BJARV were designed by Sugauchi et al., (2003) [28]. Primer BA1R was designed by Naito et al., (2001) [15]. All the primers were synthesized by Shanghai Sangon Biological Engineering Technology \& Services, China. The sequences and the positions of the primers were shown in Table 1 and Additional file 1.

Table 1 Sequences of primers used in the modified $\mathrm{nPCR}$
method
\begin{tabular}{ll} 
Primer Sequence & $\begin{array}{l}\text { Position } \\
\text { (nt) }\end{array}$ \\
\hline
\end{tabular}

First PCR

\begin{tabular}{|c|c|c|}
\hline $\mathrm{BF}$ & 5'- ACG GGG CGC ACC TCT CTT TA -3' & $1519-1538$ \\
\hline HBAS-4 V & 5'- ATA GGG GCA TाT GGT GGT CT -3' & $2316-2297$ \\
\hline PF & 5'- TTA TGC CTG CTA GGT TY' T ATC C -3' & $2635-2$ \\
\hline S4R & $5^{\prime}-$ AGA AGA TGA GGC ATA GCA GC - $3^{\prime}$ & $434-415$ \\
\hline
\end{tabular}

Second PCR

Mix A

$\begin{array}{lll}\text { HB } & \text { 5'- ACC GTG AAC GCC CAC M MGG AA -3' } & 1617-1636 \\ \text { BJA-RV } & \text { 5'- TTC TाT ATA CGG GTC AAT GTC CAT G -3' } & 1924-1900 \\ \text { DF } & \text { 5'- GCA GAA TCT TTC CAC CAG -3' } & 2853-2870 \\ \text { C1F } & \text { 5'- TCA CTC CRC CAC ACG GCA A -3' } & 3047-3065 \\ \text { C2F } & \text { 5'- CAC CGA ACA TGG AGA R'CA CA -3' } & 147-166 \\ \text { PR } & \text { 5'- TTG GTG AGT GAT TGG AGG TTG -3' } & 341-321\end{array}$

Mix B

AF1 5'- GCC TAC TAG ATT CTA TCC TAC CCA C -3' 2 645-2 669

AF2 5'- GCC TAC TAG ATT TTA TCC TAA CAG C -3' 2 645-2 669

BA1R 5'- CTC GCG GAG ATT GAC GAG ATG T-3' 111-132

Mix C

\begin{tabular}{|c|c|c|}
\hline $\mathrm{HB}$ & 5'- ACC GTG AAC GCC CAC M ${ }^{b} G G$ AA -3' & $1617-16$ \\
\hline BA & 5'- GTG TCG AGR ${ }^{C}$ AGA TCT CGA ATA -3' & 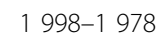 \\
\hline & 5'- TGA TCT TTA GGC CCA TGT TAG T-3' & $2192-$ \\
\hline
\end{tabular}

${ }^{\mathrm{a}} \mathrm{Y}: \mathrm{C}$ or $\mathrm{T}$.

${ }^{b} \mathrm{M}$ : $\mathrm{A}$ or $\mathrm{C}$.

c R: A or G.

\section{DNA extraction and amplification}

Hepatitis B virus DNA was extracted from $200 \mu \mathrm{l}$ serum samples using a QIAamp DNA Blood Kit (Qiagen, Hilden, Germany).

In the first round amplification, the following components were added to each microcentrifuge tube: $2 \mu \mathrm{l} 10 \times$ buffer containing $1.5 \mathrm{mM} \mathrm{MgCl}_{2}, 0.4 \mu \mathrm{ldNTP}(10 \mathrm{mM})$, $1 \mu \mathrm{l}$ each of primer BF $(10 \mu \mathrm{M})$ and HBAS $-4 \mathrm{~V}(10 \mu \mathrm{M})$, $0.6 \mu \mathrm{l}$ each primer PF $(10 \mu \mathrm{M})$ and S4R $(10 \mu \mathrm{M}), 1.5$ units of Taq DNA polymerase (Dongsheng Biotech, Guangzhou, China) and $5 \mu \mathrm{l}$ template, and then distilled deionized $\mathrm{H}_{2} \mathrm{O}\left(\mathrm{ddH}_{2} \mathrm{O}\right)$ was added to make a total reaction volume of $20 \mu \mathrm{l}$. The thermocycler (iCycler ${ }^{\mathrm{Tm}}$; Bio-Rad, Hercules, CA, USA) was programmed to predenature the samples at $95{ }^{\circ} \mathrm{C}$ for $5 \mathrm{~min}$ followed by 40 cycles: $95{ }^{\circ} \mathrm{C}$ for $30 \mathrm{~s}, 58^{\circ} \mathrm{C}$ for $30 \mathrm{~s}$, and $72{ }^{\circ} \mathrm{C}$ for $1 \mathrm{~min}$. Final elongation was at $72{ }^{\circ} \mathrm{C}$ for $7 \mathrm{~min}$. In the second round of amplification, 3 reactions were performed using the 3 mixes of primers. For the mix A reaction, the following components were added to each microcentrifuge tube: $2 \mu \mathrm{l} 10 \times$ buffer containing $1.5 \mathrm{mM} \mathrm{MgCl}_{2}, 0.4 \mu \mathrm{l}$ dNTP $(10 \mathrm{mM}), 1 \mu \mathrm{l}$ each primer $(10 \mu \mathrm{M})$ of mix A, 1 unit of Taq DNA polymerase and $1 \mu \mathrm{l}$ PCR products of the first round amplification, then $\mathrm{ddH}_{2} \mathrm{O}$ was added to make a total reaction volume of $20 \mu \mathrm{l}$. The amplification program was the same as that of the first round PCR except the elongation time was decreased to $45 \mathrm{~s}$. Amplifications with mix $B$ and mix $C$ were exactly the same as those with mix A, except for the primers of each mix. The PCR products of the second amplification, together with molecular weight standards (Takara Bio, Shiga, Japan), were electrophoresed on 2\% agarose gels stained with ethidium bromide and examined under UV light using the Bio-Rad Gel Doc 2000 System (Bio-Rad Laboratories, Segrate, Milan, Italy).

The standard precautions were taken to avoid contamination during PCR, and a negative control was included in each run of tests to ensure the specificity.

\section{Evaluating the sensitivity of the nPCR method}

The quantitation of HBV DNA was determined using the Abbott RealTime HBV DNA assay System, as described previously by Ciotti et al., (2008) [29]. HBV DNA was extracted from $200 \mu \mathrm{l}$ of serum during the sample preparation procedure. The limit of detection was $15 \mathrm{IU} / \mathrm{mL}\left(10^{1.18} \mathrm{IU} / \mathrm{mL}\right)$.

The serially diluted plasmids and 127 serum samples, of which the HBV DNA levels were quantitated using the Abbott RealTime HBV DNA Assay System, were used for evaluating the sensitivity of the nPCR method.

\section{Evaluating the specificity of the nPCR method}

First, the plasmids and the standard serum panels were applied for evaluating the specificity of the nPCR 
method. Six hundred and forty two serum samples were then assayed by the nPCR method. Among them, 130 samples were selected randomly and their PCR products were sequenced directly to confirm the genotypes and subgenotypes detected by the nPCR method (Table 2).

\section{Evaluating the reproducibility of the $\mathrm{nPCR}$ method}

The reproducibility of the $\mathrm{nPCR}$ method was evaluated using 4 plasmids of genotypes $\mathrm{A}, \mathrm{B}, \mathrm{C}$ and $\mathrm{D}\left(10^{5} \mathrm{IU} / \mathrm{mL}\right)$ and 10 clinical samples (including 2 genotype B, 3 genotype $\mathrm{C}, 3$ genotype $\mathrm{D}$ and 2 ungenotyped). For each plasmid and sample, the test was repeated ten times.

\section{DNA sequencing and phylogenic analysis}

The primers used for sequencing were as follows: outer primers of PreS/S region PF and S4R; inner primers of PreS/S region SF (nt2817-2839) 5' TCA CCA TAT ACA TGG GAA CAA GA 3', and PR3 (nt423-402) 5' CAT AGC AGC AGG ATG AAG AGG A 3'; outer primers of RT region P5 (nt972-993) 5'-GTG GCT CCA GTT CMG GAA CAG T-3', and P2 (nt2194-2173) 5'-CTA GGA GTT CCG CAG TAT GGA T-3'; inner primers of RT region P3 (nt976-993) 5'-CTC CAG TTC CGG AAC AGT-3', and P4 (2170-2153) 5'-GCA GAG GAG CCA CAA AGG-3'. Type-specific primers were adopted to verify the genotypes/subgenotypes in mixed infection samples. DNA sequencing was performed using Applied Biosystems 3730 XL DNA Analyzer.

Phylogenic analysis was carried out using MEGA 4.0 software. The phylogenic trees were constructed by the neighbor-joining method [30]. Bootstrap re-sampling and reconstruction were carried out 1000 times to confirm the reliability of the phylogenic trees.

Table 2 Samples selected randomly from the 639 clinical samples for sequencing

\begin{tabular}{|c|c|c|c|c|c|c|c|c|c|}
\hline \multirow{2}{*}{$\begin{array}{l}\text { Place } \\
\text { where } \\
\text { serum } \\
\text { samples } \\
\text { were } \\
\text { collected }\end{array}$} & \multicolumn{8}{|c|}{ Genotype/Subgenotype } & \multirow[t]{2}{*}{ Total } \\
\hline & B2 & $\begin{array}{l}\mathrm{B} 1+ \\
\mathrm{B} 2\end{array}$ & $\mathrm{C} 1$ & $\mathrm{C2}$ & D & $\begin{array}{l}\mathrm{B} 2+ \\
\mathrm{C} 2\end{array}$ & $\begin{array}{l}C 2+ \\
D\end{array}$ & $\begin{array}{l}\mathrm{B} 2+ \\
\mathrm{C} 1+\mathrm{D}\end{array}$ & \\
\hline Shandong & 0 & 0 & 1 & 10 & 0 & 2 & 0 & 0 & 13 \\
\hline Guangdong & 4 & 0 & 3 & 2 & 1 & 3 & 0 & 1 & 14 \\
\hline Guangxi & 0 & 0 & 0 & 0 & 0 & 4 & 4 & 0 & 8 \\
\hline Henan & 0 & 0 & 0 & 0 & 0 & 0 & 1 & 0 & 1 \\
\hline Hebei & 0 & 0 & 0 & 3 & 0 & 0 & 0 & 0 & 3 \\
\hline Xinjiang & 0 & 0 & 0 & 4 & 36 & 0 & 3 & 0 & 43 \\
\hline Jiangsu & 21 & 1 & 0 & 24 & 0 & 2 & 0 & 0 & 48 \\
\hline Total & 25 & 1 & 4 & 43 & 37 & 11 & 8 & 1 & 130 \\
\hline
\end{tabular}

\section{Results}

The sensitivity of the nPCR method

Serially diluted plasmids and clinical samples quantitated using the Abbott RealTime HBV DNA Assay System were used for evaluating the sensitivity of the method.

The genotypes of the plasmids could be identified when the HBV DNA load was $\geq 10^{1.18} \mathrm{IU} / \mathrm{mL}$.

Of 8 clinical samples with viral loads $<10^{1.18} \mathrm{IU} / \mathrm{mL}, 3$ (37.5\%) could be genotyped successfully by the nPCR method, while 15 of 38 (39.5\%) clinical samples with viral loads of $10^{1.18} \mathrm{IU} / \mathrm{mL}-10^{2.3} \mathrm{IU} / \mathrm{mL}$ could be genotyped successfully. However, $100 \%$ of the samples could be genotyped when the viral load was $\geq 10^{2.3} \mathrm{IU} / \mathrm{mL}$ (Table 3).

\section{The specificity of the nPCR method}

The specificity of the primer pairs was evaluated using the plasmids and standard serum panels as mentioned above. As shown in Figures 1 and 2, the individual primer pairs and three multiplex mixes of primers (mix A, mix B and mix C) exclusively amplified HBV of the respective genotype/subgenotype, and no amplification of other HBV genotypes/subgenotypes was observed.

Of the 642 samples tested, 639 (99.5\%) were genotyped and subgenotyped successfully. To confirm the results detected by the nPCR method, 130 samples were selected randomly from the 639 clinical samples as shown in Table 2 (109 single-genotype infection samples, one single-genotype infection sample coexistence of different subgenotypes and 20 samples coexistence of different genotypes), and their PCR products were sequenced directly [GenBank: JQ416163-JQ416306, HQ833465-HQ833471]. All the sequencing results were consistent with those of the nPCR method.

Table 3 Identification of HBV genotypes in clinical samples with different HBV DNA levels

\begin{tabular}{|c|c|c|c|c|c|c|c|c|}
\hline \multirow{2}{*}{$\begin{array}{l}\text { HBV-DNA } \\
\text { level } \\
\text { (IU/ml) }\end{array}$} & \multirow{2}{*}{$\begin{array}{l}\text { No. } \\
\text { tested }\end{array}$} & \multirow{2}{*}{$\begin{array}{l}\text { No. } \\
\text { successfully } \\
\text { genotyped }\end{array}$} & \multirow{2}{*}{$\begin{array}{l}\text { Percentage } \\
\text { successfully } \\
\text { genotyped } \\
(\%)\end{array}$} & \multicolumn{5}{|c|}{ Genotypes } \\
\hline & & & & $\bar{A}$ & B & C & D & Mix \\
\hline$<10^{1.18}$ & 8 & 3 & 37.5 & 0 & 0 & 2 & 1 & 0 \\
\hline $10^{1.18}-10^{2.3}$ & 38 & 15 & 39.5 & 0 & 0 & 12 & 3 & 0 \\
\hline $10^{2.3}-10^{3}$ & 25 & 25 & 100 & 0 & 1 & 21 & 0 & $1^{a}+2^{c}$ \\
\hline $10^{3}-10^{4}$ & 12 & 12 & 100 & 0 & 2 & 10 & 0 & 0 \\
\hline $10^{4}-10^{5}$ & 4 & 4 & 100 & 0 & 1 & 3 & 0 & 0 \\
\hline $10^{5}-10^{6}$ & 6 & 6 & 100 & 0 & 1 & 5 & 0 & 0 \\
\hline $10^{6}-10^{7}$ & 4 & 4 & 100 & 0 & 1 & 3 & 0 & 0 \\
\hline $10^{7}-10^{8}$ & 12 & 12 & 100 & 0 & 3 & 8 & 0 & $1^{b}$ \\
\hline $10^{8}-10^{9}$ & 18 & 18 & 100 & 0 & 4 & 13 & 0 & $1^{a}$ \\
\hline Total & 127 & 99 & 78.0 & 0 & 13 & 77 & 4 & 5 \\
\hline
\end{tabular}

$\mathrm{B}$ and $\mathrm{C}$ mixed genotype infections.

b B1 and B2 mixed subgenotype infections.

${ }^{c} \mathrm{C}$ and $\mathrm{D}$ mixed genotype infections. 


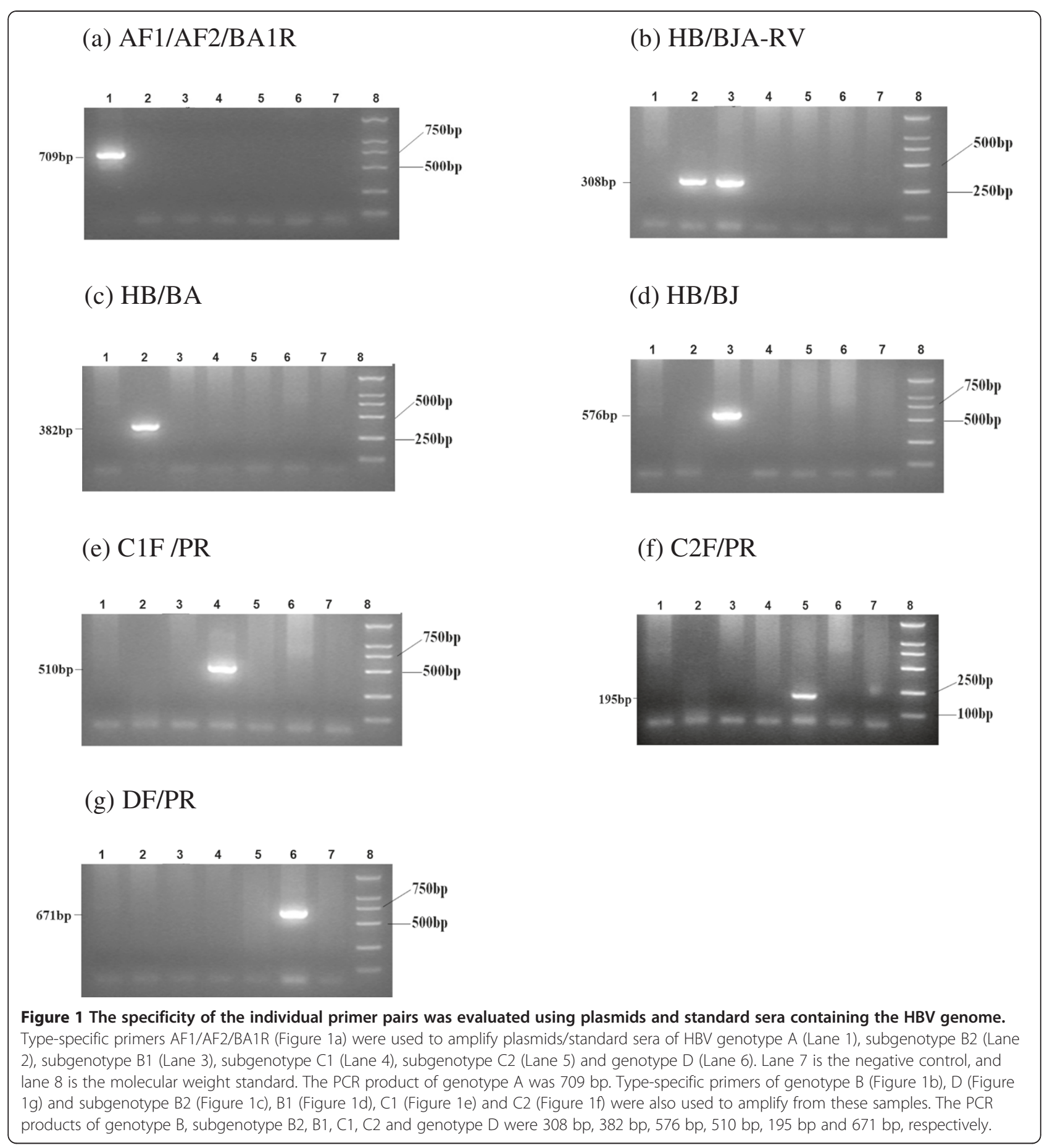

\section{The reproducibility of the nPCR method}

For 4 plasmids of genotypes A, B, C and D $\left(10^{5} \mathrm{IU} / \mathrm{mL}\right)$ and 10 clinical samples (including 2 genotype $\mathrm{B}, 3$ genotype C, 3 genotype D and 2 ungenotyped), consistent genotyping results were obtained from ten independent experiments. The ungenotyped samples could not be genotyped in these ten independent experiments.

\section{Geographical distribution of HBV genotypes and subgenotypes}

Among the 642 serum samples studied, the distribution of HBV genotypes was as follows: genotype B: 72 (11.2\%); genotype C: 438 (68.2\%); genotype D: 46 (7.2\%) and $84(13.1 \%)$ patients were mixed genotypes. There was no other genotype found in this study. The 


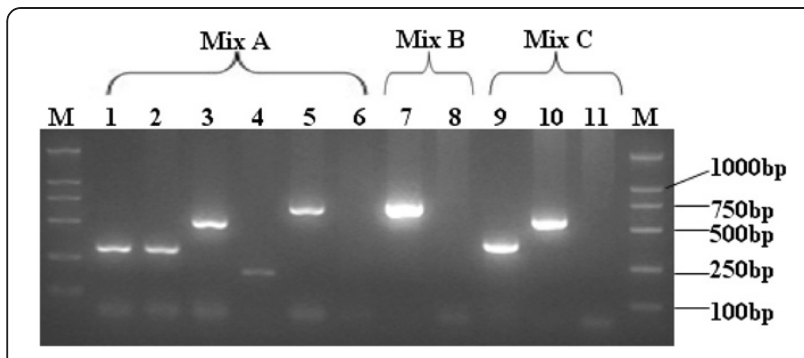

Figure 2 The specificity of the 3 multiplex mixes of primers ( $A$, $B$ and $C$ ) evaluated using plasmids and standard sera containing the HBV genome. M: molecular weight standards; Lane 6, 8 and 11: negative controls; Lane1 and 9: standard sera of subgenotype B2; Lane 2 and 10: plasmid of subgenotype B1; Lane 3: standard serum of subgenotype C1; Lane 4: plasmid of subgenotype C2; Lane 5: plasmid of genotype D; Lane 7: plasmid of genotype A.

sequencing analysis of HBV DNA from the 20 samples with mixed $\mathrm{HBV}$ genotypes confirmed the results of nPCR methods.
Geographically, the predominant genotype in China was genotype C (Figure 3 and Additional file 2), accounting for $91.5 \%(182 / 199)$ in the north, $89.6 \%$ (60/ $67)$ in the central area, $71.6 \%(106 / 148)$ in the east, $55.5 \%(61 / 110)$ in the south and $24.6 \%(29 / 118)$ in the west of China. Genotype B was mainly found in the south $(21.8 \%, 24 / 110)$, the east $(18.9 \%, 28 / 148)$ and the west $(11.9 \%, 29 / 118)$ of China, while it was only $2.0 \%$ in the north and 3.0\% in central China. Genotype D was prevalent in the west (Xinjiang Uygur Autonomous Region). As for mixed genotype infection, $\mathrm{B}+\mathrm{C}$ was predominant and could be detected in all part of China.

The major subgenotypes were B2 $(87.5 \%, 63 / 72)$ among genotype B, and C2 $(92.9 \%, 407 / 438)$ of genotype C (Table 4), and they were the predominant subgenotype in all part of China as well. Subgenotype $\mathrm{C} 1$ was mainly found in the south of China. Subgenotype B1 $(0.6 \%, 4 / 642)$ was found in Xinjiang. Mixed subgenotypes B1 + B2 (0.6\%, $4 / 642)$ and $\mathrm{C} 1+\mathrm{C} 2(0.9 \%, 6 / 642)$ were sporadically

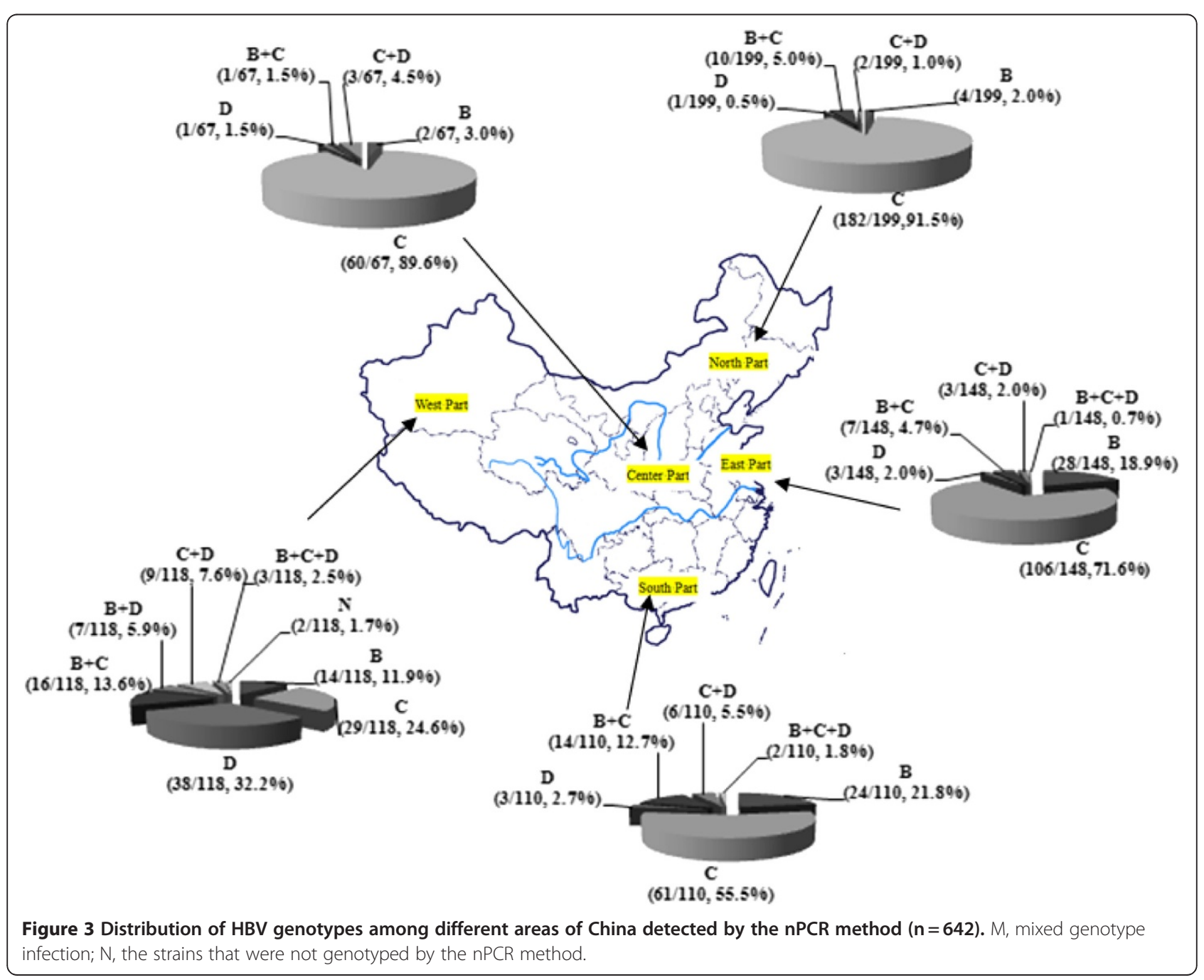


Table 4 Distribution of HBV subgenotype B and C in different areas of China

\begin{tabular}{|c|c|c|c|c|c|c|c|}
\hline & \multicolumn{4}{|c|}{$\begin{array}{l}\text { Sub-genotype B\% } \\
(\mathrm{m} / \mathrm{n})\end{array}$} & \multicolumn{3}{|c|}{$\begin{array}{l}\text { Sub-genotype C\% } \\
(\mathrm{m} / \mathrm{n})\end{array}$} \\
\hline & $\overline{B 1}$ & B2 & $B 1+B 2$ & $B^{N}$ & $\overline{\mathrm{C} 1}$ & C2 & $\mathrm{C} 1+\mathrm{C} 2$ \\
\hline East & & $96.4(27 / 28)$ & $3.6(1 / 28)$ & & $0.9(1 / 106)$ & $99.1(105 / 106)$ & \\
\hline West & $28.6(4 / 14)$ & $42.9(6 / 14)$ & $21.4(3 / 14)$ & $7.1(1 / 14)$ & & $93.1(27 / 29)$ & $6.9(2 / 29)$ \\
\hline South & & $100(24 / 24)$ & & & $39.3(24 / 61)$ & $54.1(33 / 61)$ & $6.6(4 / 61)$ \\
\hline North & & $100(4 / 4)$ & & & & $100(182 / 182)$ & \\
\hline Center & & $100(2 / 2)$ & & & & $100(60 / 60)$ & \\
\hline Total & $5.6(4 / 72)$ & $87.5(63 / 72)$ & $5.6(4 / 72)$ & $1.4(1 / 72)$ & $5.7(25 / 438)$ & $92.9(407 / 438)$ & $1.4(6 / 438)$ \\
\hline
\end{tabular}

$\mathrm{N}$ : the strain that could not be subgenotyped by $\mathrm{nPCR}$.

distributed in the east, the west and the south of China, and had rarely been reported before.

\section{Discussions}

A relatively simple, rapid, economic and practical genotyping system with high sensitivity and specificity was established based on the methods developed by Naito et al., (2001) [15] and Sugauchi et al., (2003) [28]. Compared with the classical type-specific PCR method established by Naito et al., (2001) [15], low-cost common Taq polymerase was used in our method. The cost of the common Taq polymerase is roughly $40 \%$ of AmpliTaq Gold DNA polymerase used in Naito's method. When common Taq polymerase was employed instead of AmpliTaq Gold DNA polymerase in Naito's method, the specificity of the method was reduced (unpublished data). Only a single nucleotide difference between typespecific primers (e.g. antisense primer BB1R) and reference sequences of different genotypes may allow extension of mismatched primer-template. It was reported that, in some instances, a single terminal 3'-mismatched base did allow PCR amplification to proceed [31,32], which reduced the specificity of type-specific PCR method. In our method, primers specific for each HBV genotype or subgenotype differed by $\geq 3$ nucleotides ( $\geq 2$ nucleotides at the 3 ' end of the sequences). Double mismatches at 3 ' end decreased the extension of mismatched primer-template. The sequencing results of 130 serum samples selected randomly from the 639 samples, confirmed the specificity of our nPCR method.

The sensitivity of the nPCR method was evaluated using serially diluted plasmids $\left(10^{1}-10^{9} \mathrm{IU} / \mathrm{mL}\right)$ and 127 clinical samples, in which HBV DNA was quantitated using the Abbott RealTime HBV DNA Assay System. The limit of detection was $<10^{1.18} \mathrm{IU} / \mathrm{mL}$ (Table 3) and $100 \%$ of the samples could be genotyped when the viral load was $\geq 10^{2.3} \mathrm{IU} / \mathrm{mL}$, which was sufficient for routine genotyping and subgenotyping. The sensitivity of Chen's method [12] using single-round PCR for detection of genotype $\mathrm{B}$ and $\mathrm{C}$ was $>10^{4} \mathrm{IU} / \mathrm{mL}$ as we repeated this method in our lab. Therefore, we developed a nested PCR method for HBV genotyping and subgenotyping to improve the lower limit of single-round PCR method.

On the other hand, there were two fragments generated after the first round PCR reaction in the $\mathrm{nPCR}$ method. One of the fragments, for the specific detection of genotype $\mathrm{B}$, was located mainly in the $\mathrm{preC} / \mathrm{C}$ region of the HBV genome, and another one, for detecting genotypes $\mathrm{C}$ and $\mathrm{D}$, was mainly in the $\mathrm{preS} / \mathrm{S}$ region (see Supplementary data 1). This design increased the sensitivity and specificity of the detection of genotypes $\mathrm{B}, \mathrm{C}$ and $\mathrm{D}$, while mixed strains could be detected more sensitively as well. In this study, $13.1 \%(84 / 642)$ of the samples assayed by the nPCR method were mixed genotypes. The sequencing analysis of HBV DNA from the 21 cases with mixed HBV infection confirmed the results of the nPCR method (random sampling cases were $1 / 5$ of total number of mixed infection samples).

Only three of the 642 samples could not be genotyped or subgenotyped by the nPCR method. Two of the three samples could not be genotyped and another one was identified as genotype B but could not be subgenotyped further by the nPCR method. The sequencing results of the three samples revealed that the first 2 samples were $\mathrm{C} / \mathrm{D}$ recombinants. It was reported that this kind of $\mathrm{C} / \mathrm{D}$ hybrid emerged in the $\mathrm{preS} / \mathrm{S}$ region between genotype $\mathrm{D}$ and subgenotype $\mathrm{C} 2$, and belonged to genotype $\mathrm{C}$. The recombination fragment of genotype $\mathrm{D}$ was located at the nt 10-799 or nt 10-1 499 region [33]. As primers DF and C2F were designed at nt2 853-2 870 and nt147166 respectively, the nPCR method could not detect this kind of C/D recombinant. Until now, whole genome sequencing was the only effective method to detect $\mathrm{C} / \mathrm{D}$ recombinants. The third sample, which was identified as subgenotype B2 by sequencing, had a mutation in the region where primer $\mathrm{BA}$ was designed, and the mutation was exactly at the nucleotide position matching the 3' end of the primer, which led to failure of detection by the nPCR method. However, the frequency of this kind of mutation was relatively low. 
The present study demonstrated that genotype B, C and $\mathrm{D}$ were circulating in China. The results revealed marked geographical differences in the distribution of HBV genotypes. In the north and central China, genotype $\mathrm{C}$ was the predominant while the percentage of other genotypes was low. In the south and the east of China, the dominant genotypes were $\mathrm{C}$ and $\mathrm{B}$. In the west, the dominant genotype was D. It was obvious that the percentage of mixed genotype infection was high in the south and the west of China. As previously reported, HBV infection rate with multiple genotypes was found to be $31 \%$ in Shenzhen [34] (in the south of China), and $22 \%-43.8 \%$ in Xinjiang [35,36] (in the west of China). In China, studies on the subgenotype of HBV were seldom reported. The predominant subgenotype was B2 and C2 in all parts of China.

\section{Conclusions}

In conclusion, an accurate, sensitive and cost-effective nPCR genotyping method for the simultaneous detection of the HBV genotypes A to D and subgenotypes B and C has been established. The geographical distribution of HBV genotypes and subgenotypes in the mainland of China was mapped at the same time. Further investigation of HBV genotypes and subgenotypes using this method will enrich the epidemiological data for HBV in regions where genotypes A-D are predominant. This method will provide a useful tool for clinical and epidemiological applications.

\section{Additional files}

Additional file 1 Figure S1: The positions of the type-specific primers for the improved nPCR method.

Additional file $\mathbf{2}$ Table S1: The genotype distribution in nine provinces located in different areas of China.

\section{Abbreviations \\ $\mathrm{ddH}_{2} \mathrm{O}$ : Distilled deionized $\mathrm{H}_{2} \mathrm{O}$; HBsAg: Hepatitis B surface antigen; HBV: Hepatitis B virus; nPCR: Nested polymerase chain reaction; PreC: Pre Core; PreS: Pre Surface; RFLP: Restriction fragment length polymorphism; $\mathrm{RT}$ : Reverse transcriptase.}

\section{Competing interests}

The authors declare that they have no competing interests.

\section{Authors' contributions}

$J L, H Z, J W, H J$ designed this study; JJN, KXS, LY, JW, HJ, JXY, MSS performed lab work; JJN and KXS participated in data analysis. JJN and JL drafted the manuscript. $H Z$, JL, LW, FML, TL critically reviewed the manuscript. All the authors read and approved the final manuscript.

\section{Acknowledgments}

The authors thank Dr. Kenji Abe (National Institute of Infectious Diseases, Japan), Prof. Stephen Locarnini (Victorian Infectious Diseases Reference Laboratory, Australia) and Prof. Jinlin Hou (Nanfang Hospital of Southern Medical University, China) for providing valuable plasmids of cloned HBV DNA.
The authors would also like to thank Dr. Shuang Liu, Dr. Chengzhi Wang, Dr. Stephen Lou, and Dr. Jeremy Allen for critically proofreading this manuscript. This study was supported by the Major Science and Technology Special Project of the Eleventh Five-year Plan of China (2008ZX10002-001, 2008ZX10002-012).

Received: 15 June 2011 Accepted: 11 June 2012 Published: 19 June 2012

\section{References}

1. Kidd-Ljunggren K, Miyakawa Y, Kidd AH: Genetic variability in hepatitis B viruses. J Gen Virol 2002, 83:1267-1280.

2. Kramvis A, Kew M, Francois G: Hepatitis B virus genotypes. Vaccine 2005, 23:2409-2423

3. Okamoto H, Tsuda F, Sakugawa H, Sastrosoewignjo RI, Imai M, Miyakawa Y, Mayumi M: Typing hepatitis B virus by homology in nucleotide sequence: comparison of surface antigen subtypes. J Gen Virol 1988, 69:2575-2583.

4. Norder H, Hammas B, Lofdahl S, Courouce AM, Magnius LO: Comparison of the amino acid sequences of nine different serotypes of hepatitis $B$ surface antigen and genomic classification of the corresponding hepatitis B virus strains. J Gen Virol 1992, 73:1201-1208.

5. Stuyver L, De Gendt S, Van Geyt C, Zoulim F, Fried M, Schinazi RF, Rossau R: A new genotype of hepatitis $B$ virus: complete genome and phylogenetic relatedness. J Gen Virol 2000, 81:67-74.

6. Arauz-Ruiz P, Norder H, Robertson BH, Magnius LO: Genotype H: a new Amerindian genotype of hepatitis B virus revealed in Central America. J Gen Virol 2002, 83:2059-2073.

7. Kay A, Zoulim F: Hepatitis B virus genetic variability and evolution. Virus Res 2007, 127:164-176.

8. Liang XF, Bi SL, Yang WZ, Wang LD, Cui G, Cui FQ, Zhang Y, Liu JH, Gong $X H$, Chen YS, Wang FZ, Zheng H, Wang F, Guo J, Jia ZY, Ma JC, Wang HQ, Luo HM, Li L, Jin SG, Hadler SC, Wang Y: Epidemiological serosurvey of hepatitis B in China-declining HBV prevalence due to hepatitis B vaccination. Vaccine 2009, 27:6550-6557.

9. Zeng G, Wang Z, Wen S, Jiang J, Wang L, Cheng J, Tan D, Xiao F, Ma S, Li W, Luo K, Naoumov NV, Hou J: Geographic distribution, virologic and clinical characteristics of hepatitis B virus genotypes in China. J Viral Hepatitis 2005, 12:609-617.

10. Wang ZH, Huang YH, Wen SJ, Zhou B, Hou JL: Hepatitis B virus genotypes and subgenotypes in China. Hepatol Res 2007, 37(Suppl 1):36-41.

11. Li YJ, Zhuang H, Li J, Dong QM, Chen YJ, Niu JQ, Ma WM, Zhao W, Zhao BA, Zhong JQ: Distribution and clinical significance of hepatitis B virus (HBV) genotypes and subtypes in HBV-infected patients. Chin J Hepatol 2005, 13:724-729.

12. Chen JS, Yin JH, Tan XJ, Zhang HQ, Zhang HW, Chen BC, Chang WJ, Schaefer S, Cao GW: Improved multiplex-PCR to identify hepatitis B virus genotypes A-F and subgenotypes B1, B2, C1 and C2. J Clin Virol 2007, 38:238-243.

13. Liu WC, Lindh $M$, Buti $M$, Phiet $P H$, Mizokami $M$, Li HH, Sun KT, Yong KC, Cheng PN, Wu IC, Chang TT: Genotyping of hepatitis B virus genotypes $A$ to $G$ by multiplex polymerase chain reaction. Intervirology 2008, 51:247-252.

14. Kirschberg O, Schuttler C, Repp R, Schaefer S: A multiplex-PCR to identify hepatitis B virus - genotypes A-F. J Clin Virol 2004, 29:39-43.

15. Naito H, Hayashi S, Abe K: Rapid and specific genotyping system for hepatitis B virus corresponding to six major genotypes by PCR using type-specific primers. J Clin Microbiol 2001, 39:362-364.

16. Mizokami M, Nakano T, Orito E, Tanaka Y, Sakugawa H, Mukaide M, Robertson $\mathrm{BH}$ : Hepatitis $\mathrm{B}$ virus genotype assignment using restriction fragment length polymorphism patterns. FEBS Lett 1999, 450:66-71.

17. Zeng GB, Wen SJ, Wang ZH, Yan L, Sun J, Hou JL: A novel hepatitis B virus genotyping system by using restriction fragment length polymorphism patterns of S gene amplicons. World J Gastroenterol 2004, 10:3132-3136.

18. Lindh M, Gonzalez JE, Norkrans G, Horal P: Genotyping of hepatitis B virus by restriction pattern analysis of a pre-S amplicon. J Virol Methods 1998, 72:163-174.

19. Osiowy C, Giles E: Evaluation of the INNO-LiPA HBV genotyping assay for determination of hepatitis B virus genotype. J Clin Microbiol 2003, 41:5473-5477. 
20. Tanaka Y, Sugauchi F, Matsuuraa K, Naganuma H, Tatematsu K, Takagi K, Hiramatsu K, Kani S, Gotoh T, Wakimoto Y, Mizokami M: Evaluation of hepatitis B virus genotyping EIA kit. Rinsho Byori 2009, 57:42-47.

21. Usuda S, Okamoto H, Tanaka T, Kidd-Ljunggren K, Holland PV, Miyakawa Y, Mayumi M: Differentiation of hepatitis $B$ virus genotypes $D$ and $E$ by ELISA using monoclonal antibodies to epitopes on the preS2-region product. J Virol Methods 2000, 87:81-89.

22. Guirgis BSS, Abbas RO, Azzazy HME: Hepatitis B virus genotyping: current methods and clinical implications. Int J Infect Dis 2010, 14:E941-E953.

23. Yin JH, Zhang HW, He YC, Xie JX, Liu SJ, Chang WJ, Tan XJ, Gu CY, Lu W, Wang HY, Bi SL, Cui FQ, Liang XF, Schaefer S, Cao GW: Distribution and hepatocellular carcinoma-related viral properties of hepatitis $B$ virus genotypes in Mainland China: a community-based study. Cancer Epidemiol Biomarkers Prev 2010, 19:777-786.

24. Zhang XR, Li W, Shen YY, Ren LF, Li Q, Shen R, Zhao HP: Comparison of nested PCR-restriction fragment length polymorphism with mutiple-PCR by type-specific primers for HBV genotyping and subgenotyping. Acad J PLA Postgrad Med Sch 2008, 29:280-282.

25. Sun J, Wang C, Wen SJ, Wang ZH, Hou JL: Construction of whole-genome lamivudine-resistant hepatitis B virus mutant and its replication and expression in HepG2 cells. J South Med Univ 2007, 27:991-993.

26. Chen RYM, Edwards R, Shaw T, Colledge D, Delaney WE, Isom H, Bowden S, Desmond P, Locarnini SA: Effect of the G1896A precore mutation on drug sensitivity and replication yield of lamivudine-resistant HBV in vitro. Hepatology 2003, 37:27-35.

27. Wang J, Gao JW, Li J, Zhuang H, Wang J, Li YJ, Jin H: Establishment of a semi-nested PCR for identifying the sub-genotypes (Ba and Bj) of hepatitis B virus of genotype B. Chin J Epidemiol 2008, 29:177-180.

28. Sugauchi F, Orito E, Ichida T, Kato H, Sakugawa H, Kakumu S, Ishida T, Chutaputti A, Lai CL, Gish RG, Ueda R, Miyakawa Y, Mizokami M: Epidemiologic and virologic characteristics of hepatitis $B$ virus genotype B having the recombination with genotype C. Gastroenterology 2003, 124:925-932.

29. Ciotti M, Marcuccilli F, Guenci T, Prignano MG, Perno CF: Evaluation of the Abbott RealTime HBV DNA assay and comparison to the Cobas AmpliPrep/Cobas TaqMan 48 assay in monitoring patients with chronic cases of hepatitis B. J Clin Microbiol 2008, 46:1517-1519.

30. Saitou N, Nei M: The neighbor-joining method: a new method for reconstructing phylogenetic trees. Mol Biol Evol 1987, 4:406-425.

31. Ayyadevara S, Thaden JJ, Reis RJS: Discrimination of primer 3 '-nucleotide mismatch by Taq DNA polymerase during polymerase chain reaction. Anal Biochem 2000, 284:11-18.

32. Newton CR, Graham A, Heptinstall LE, Powell SJ, Summers C, Kalsheker N, Smith JC, Markham AF: Analysis of any point mutation in DNA. The ampliflcation refractory mutation system (ARMS). Nucleic Acids Res 1989, 17:2503-2516

33. Wang ZH, Liu ZH, Zeng GB, Wen SJ, Qi YP, Ma SW, Naoumov NV, Hou JL: A new intertype recombinant between genotypes $C$ and $D$ of hepatitis $B$ virus identified in China. J Gen Virol 2005, 86:985-990.

34. Dai JY, Shi ZL, Dai Y, Du H, Chen DH, Wang SY: Genotyping of HBV DNA in Shenzhen and clinical manifestations. Chin J Hepatol 2004, 12:199-200.

35. Xu H, Zhang YX, Xiao L, Lu XB, Wei L, Cong X: Relationship between the distribution of hepatitis $B$ virus genotypes and clinical types of the disease in Han nationality hepatitis B patients in Xinjiang. Chin J Hepatol 2005, 13:848-849.

36. Lu XB, Wang XL, Deng GH, Kuang XM, Aman GL, Zhang YX, Zhang JL, Wang YM: Distribution and characteristics of hepatitis $B$ virus genotypes in Uighur patients with chronic hepatitis B in Xinjiang province of China. Chin J Hepatol 2007, 15:241-244.

doi:10.1186/1743-422X-9-121

Cite this article as: Nie et al:: A type-specific nested PCR assay established and applied for investigation of HBV genotype and subgenotype in Chinese patients with chronic HBV infection. Virology Journal 2012 9:121.

\section{Submit your next manuscript to BioMed Central and take full advantage of:}

- Convenient online submission

- Thorough peer review

- No space constraints or color figure charges

- Immediate publication on acceptance

- Inclusion in PubMed, CAS, Scopus and Google Scholar

- Research which is freely available for redistribution

Submit your manuscript at www.biomedcentral.com/submit
C BioMed Central 